\title{
FAKTOR-FAKTOR YANG MEMPENGARUHI PENDAPATAN PETANI KOPI DI KECAMATAN BINTANG KABUPATEN ACEH TENGAH (STUDI KASUS DESA WAKIL JALIL)
}

\author{
Cut Putri Mellita Sari ${ }^{\mathrm{a}^{*}, \text { Juliana Fitri }} \mathrm{a}^{\mathrm{*}}$ \\ ${ }^{a}$ Fakultas Ekonomi dan Bisnis Universitas Malikussaleh \\ *Corresponding author: cmellita0674@gmail.com \\ *juliana09fitri@gmail.com
}

ARTICLE INFORMATION ABSTRACT

Keywords:Land area, Labor and

Production costs, income
The purpose of the study is to find out the affecting Factors to the Income of Coffee Farmers in the District of Bintang Tengah Aceh Tengah (Case Study of Wakil Jalil Village), including variables on land area, labor and production costs. The data collected in this study are primary data from 94 respondents. The research method uses multiple linear regression model The results show that, partially the area of land, labor and production costs have a positive effect on income, simultaneously the area of land, labor and production costs also affect income.

\section{PENDAHULUAN}

Kecamatan Bintang merupakan wilayah yang berada di kabupaten aceh tengah. Secara geografis wilayah Kecamatan Bintang berada di daerah pegunungan, dimana mayoritas penduduknya berprofesi sebagai petani khususnya petani kopi. Komoditas pertanian terutama pada pertanian kopi terus diusahakan dan ditingkatkan, dikarenakan kebutuhan masyarakat akan mengkonsumsi kopi sehari-hari terus meningkat menyebabkan akan tingginya permintaan akan biji kopi tersebut. Untuk itu pemerintah Kabupaten Aceh Tengah harus memperhatikan para petani kopi tersebut memberikan pelatihan dan teknik cara budidaya kopi yang lebih baik,dimana para petani tidak harus menggunakan pupuk anorganik tapi menggunakan pupuk organik agar hasil kopi tersebut berkualitas tinggi dan tingginya harga di pasaran karena kopi tersebut kopi organik.

Sektor pertanian dan perkebunan menjadi pekerjaan paling banyak di tekuni oleh penduduk Aceh Tengah. Kawasan Kabupaten Aceh Tengah merupakan mayoritas penduduknya bekerja di sektor pertanian dan perkebunan. Dimana banyaknya kebun kopi yang dimiliki serta banyaknya hasil produksi kopi yang dihasilkan di daerah ini. Kabupaten Aceh Tengah merupakan daerah yang memiliki kebun kopi terluas di Provinsi Aceh(Setiyowati, 2016)
Tanaman kopi merupakan komoditas unggulan bagi petani kopi untuk diusahakan dibanding dengan komoditas lainya seperti komoditas perkebunan yang semusiman, karena kopi merupakan usaha yang menjanjikan bagi masyarakat untuk memenuhi kebutuhan dan meningkatkan kesejahteraan bagi (Maihani, 2017). Oleh karena itu petani daerah Kecamatan Bintang lebih memilih mengembangkan usaha kopi untuk diusahana karena hasil dari kopi tersebut lebih menjanjikan bagi kehidupan masyarakat yang ada di Kecamatan Bintang. Usaha tani ini memberikan konstribusi yang sangat banyak bagi pendapatan petani kopi di kecamatan Bintang. Komoditas kopi merupakan komoditas unggulan dimana luas area panen sekitar 180 ha dan produksinya sekitar 1.652 (ton) dibandingkan dengan tanaman yang lainnnya(Kantor Camat Kecamatan Bintang, 2018)Untuk lebih jelasnya luas areal dan produksi tanaman yang lainnya yaitu tanaman perkebunan musiman tahun 2018 di Kecamatan Bintang sebagai berikut:

Tabel 1

Luas Areal Dan Produksi Komoditi Tanaman Perkebunan Lainnya Di Kecamatan Bintang Kabupaten Aceh Tengah

\begin{tabular}{|l|l|l|l|}
\hline No & Komodi & $\begin{array}{l}\text { Luas } \\
\text { panen } \\
\text { (Ha) }\end{array}$ & $\begin{array}{l}\text { Produksi } \\
\text { (ton) }\end{array}$ \\
\hline 1 & Tebu & - & - \\
\hline
\end{tabular}




\begin{tabular}{|l|l|l|l|}
\hline 2 & Kapulaga & - & - \\
\hline 3 & Pinang & 2 & 0,8 \\
\hline 4 & Aren & 3 & 12 \\
\hline 5 & Kelapa & 1 & 1,3 \\
\hline $6 \mathrm{~S}$ & Lada & 1 & 0,1 \\
\hline 7 & Kapuk & - & - \\
\hline 8 & Tembakau & 6 & 88 \\
\hline 9 & Seriwangi & - & - \\
\hline 10 & Nilam & - & - \\
\hline 11 & Kopi & 180 & 1.652 \\
\hline 12 & Cassiva & 3 & 3 \\
\hline 13 & Kakao & 4 & 34 \\
\hline 14 & Kemiri & 2 & 1,8 \\
\hline
\end{tabular}

Sumber : Kantor Camat Kecamatan Bintang, Tahun 2018

Petani di Kecamatan Bintang sering mengalami hambatan dalam kegiatan produksi usaha tani kopi seperti terserang hama penyakit, menghadapi cuaca yang sering berubah-ubah, dimana kondisi cuaca yang tidak stabil kualitas kopi akan memburuk, dengan kualitas yang tidak bagus maka pembeli kopi membeli kopi dari petani hanya sedikit, karna pembeli kopi melihat dari kualitas kopi tersebut. Dalam upaya meningkatkan pendapatan masyarakat dan kesejahteraan sering di hadapkan dengan permasalahan yaitu faktor-faktor yang mempengaruhi pendapatan petani yaitu faktor luas lahan, dimana luas lahan merupakan faktor utama dalam sebuah usaha pertanian semakin luas lahan yang digarap maka semakin banyak hasil yang diperoleh begitu juga sebaliknya (Mubyarto, 2007) Tenaga kerja merupakan faktor pendukung dalam suatu usaha, tenaga kerja yang bekerja sebagian dari luar keluarganya. Biaya produksi juga merupakan aktor utama dalam keberhasilan suatu usaha pertanian, dimana semakin besar biaya yang dikeluaran maka semakin banyak hasil yang diperoleh, begitu juga sebaliknya. Penelitian ini bertujuan untuk mengetahui seberapa besar pengaruh luas lahan, tenaga kerja dan biaya produksi terhadap pendapatan petani kopi di Kecamatan Bintang Kabupaten Aceh Tengah.

\section{LANDASAN TEORITIS}

\section{Pengertian Pendapatan}

Pada umumnya sebagian pendapatan yang dihasilkan oleh perusahaan berasal dari aktivitas utama perusahaan yang bersifat rutin, namun adakalanya perusahaan juga dapat memperoleh atau menambahkan pendapatan dari aktivitasaktivitas non operasional yang bersifat tidak rutin dari perusahaan tersebut.

Menurut (Mubyarto, 2004) menyebutkan bahwa pendapatan jumlah uang yang diterima dan diberikan kepada subjek ekonomi berdasarkan prestasi yang diserahkan yaitu pendapatan atas pekerjaan, pendapatan dari profesi yang dilakukan sendiri dan pendapatan dari kejayaan dari subsistem secara wajar dapat diharapkan sedikit kebutuhan primer.

\section{Faktor-Faktor Yang Mempengaruhi Pendapatan}

\section{Luas Lahan}

Luas lahan akan mempengaruhi skala usaha yang pada akhirnya mempengaruhi besar kecilnya jumlah produksi suatu usaha pertanian. Besar atau kecilnya jumlah produksi suatu usaha pertanian akan mempengaruhi pendapatan petani, yang mana petani yang mempunyai luas lahan yang luas akan mendapatkan hasil produksi yang banyak sehingga memperoleh pendapatan yang banyak pula, sedangkan petani yang hanya memiliki luas lahan yang sempit maka menghasilkan produksi sedikit dan akan memperoleh penghasilan yang sedikit pula.

\section{Tenaga Kerja}

Tenaga kerja merupakan salah satu unsur yang penting dalam pengembanagan usaha sehingga mampu mengelola produksi yang tepat serta dapat mencapai sasaran sehingga melalui perkembangan perusahaan dapat memberikan mamfaat kepada pembangunan ekonomi dan dapat menyerap tenaga kerja (Simanjuntak, 2011) mengungkapkan tenaga kerja adalah sebagai jumlah penduduk usia 10 tahun atau lebih yang bekerja, mencari pekerjaan dan sedang melakukan kegiatan lain, seerti sekolah maupun mengurus rumah tangga dan penerimaan pendapatan.

\section{Biaya Produksi}

Biaya produksi adalah sejumlah biaya yang digunakan dalam menjalankan kegiatan-kegiatan produksi. Menurut (Amirullah Dan Harjanto, 2005) banyak kalangan yang memandang bahwa biaya produksi bukanlah segala-galanya dalam sebuah usaha pertanian. Beberapa biaya produksi bervariasi dengan outputsementara yang lainnya tetap sepanjang kegiatan itu tetap memproduksi dengan output yang memaksimumkan laba melalui total keseluruhan jumlah biaya. Ada jumlah biaya produksi yang digunakan dalam suatu usaha yaitu, Biaya Total (Total Cost/Tc), Biaya Marjinal (Marginal Cost/Mc) dan Biaya Total Rata-rata (Average Total Cost/Atc) 
Hubungan Antar Variabel

Hubungan Luas Lahan Dengan Pendapatan Petani

Menurut (Mubyarto, 2007) Luas lahan adalah keseluruhan wilayah yang menjadi tempat penanaman atau mengerjakan proses penanaman, luas lahan menjamin jumlah atau hasil yang akan diperoleh petani. Jika luas lahan meningkat pendapatan petani akan meningkat, demikian juga sebaliknya. Sehingga hubungan antara luas lahan dengan pendapatan petani merupakan hubungan yang positif.

\section{Hubungan Tenaga Kerja Terhadap Pendapatan Petani}

Tenaga kerja merupakan unsur produksi yang kedua dalam usaha tani. Kerja seseorang itu dipengaruhi dari tingkat umur, pendidikan, keterampilan, pengalaman, dan tingkat kesehatan. Sedangkan pendapatan merupakan selisih antara penerimaan dan semua biaya. Hubungan keduanya yaitu semakin tinggi pendidikan tenaga kerja, semakin terampil, dan berpengalaman maka akan semakin baik hasil produksi yang akan di produksikan (Soekartawi, 2011).

Hubungan Biaya Produksi Dengan Pendapatan Petani

Biaya produksi merupakan sejumlah biaya yang digunakan dalam menjalankan kegiatankegiatan produksi. Sedangkan pendapatan adalah selisih antara penerimaan dan semua biaya. Jika biaya produksi meningkat pendapatan berkurang, demikian juga sebaliknya. Hubungan keduanya merupakan semakin besar biaya produksi yang dikeluarkan dan semakin kecil maka akan mempengaruhi pendapatan yang akan diterima (Soekartawi, 2006)

\section{METODE PENELITIAN}

\section{Objek Dan Lokasi Penelitian}

Objek dalam penelitian ini adalah luas lahan, tenaga kerja dan biaya produksi terhadap pendapatan petani kopi di Kecamatan Bintang Kabupaten Aceh Tengah. Lokasi penelitian ini yaitu di desa yang mempunyai lahan kopi di Kecamatan Bintang Kabupaten Aceh Tengah, yaitu desa Wakil Jalil.

\section{Populasi Dan Sampel}

Populasi adalah keseluruhan dari unit-unit analisa yang akan diduga(Supranto, 2003). Karakteristik responden dalam penelitian ini adalah petani kopi yang ada di desa Wakil Jalil Kecamatan Bintang, berdasarkan hasil wawancara dengan geucik desa wakil jalil jumlah petani kopi di desa tersebut berjumlah 1,500 orang.

Sampel merupakan bagian dari populasi yang diambil melalui cara-cara atau menariksampel dengan cara proporsi dari populasi yang ada dan juga memiliki karakteristik tertentu jelas dan lengkap yang dianggap bisa mewakili populasi(Sugiyono, 2015). Dalam penelitian ini teknik pengambilan sampel yang digunakan adalah Proportional Stratified Sampling atau pengembalian sampel secara acak stratifikasi. Agar perimbangan jumlah sampel dari masingmasing strata memadai, maka digunakan rumus slovin sebagai berikut

Keterangan :

$$
\mathrm{n}=\frac{N}{1+N e^{2}}
$$

$$
\begin{aligned}
& 1=\text { Kostanta } \\
& \mathrm{n}=\text { Ukuran Sampel } \\
& \mathrm{N}=\text { Ukuran populasi } \\
& \mathrm{e}^{2}=\text { Tingkat kepercayaan atau } \\
& \text { ketepatan }
\end{aligned}
$$

Dengan populasi sebesar 1,500 dan persentase sebesar 0,10 (10\%), maka jumlah sampel minimal adalah.

$$
n=\frac{1,500}{1+1,500(0,01)}=\frac{1,500}{1+15}=\frac{1,500}{16}=93,75
$$

menjadi 94)

Dengan demikianjumlah sampel yang diambil dalam penelitian ini adalah sebanyak 94 petani kopi yang ada di Desa Wakil Jalil Kecamatan Bintang.

\section{Definisi Operasional Variabel}

1. Pendapatan (Y), merupakan pendapatan bersih yang diperoleh dalam pertanian kopi dengan satuan (Rupiah/panen).

2. Luas lahan (X1), adalah suatu tempat atau tanah yang mempunyai luas tertentu yang digunakan untuk usaha pertanian dengan satuan (Ha).

3. Tenaga kerja (X2), merupakan faktor produksi dalam usaha tani, banyaknya orang yang bekerja untuk menghasilkan produksi dengan satuan (Jiwa).

4. Biaya produksi (X3), Biaya produksi adalah sejumlah biaya yang digunakan dalam menjalankan kegiatan-kegiatan produksi, dengan satuan (Rupiah). 


\section{Metode Analisis Data}

Dalam menganalisa data yang bertujuan untuk memperoleh data penulisan ini, penulis menggunakan metode kuantitatif, yaitu dengan suatu metode menganalisis data yang diperoleh dalam bentuk angka dan selanjutnya akan dibahas serta dianalisis dengan menggunakan alat statistik menggunakan metode Analisis Regresi Linear Berganda melalui program Eviews 9.

$$
\operatorname{LnY}=\beta_{0}+\beta_{1} X_{1}+\beta_{2} X_{2}+\beta_{3} \ln X_{2}+e i
$$

Dimana :

$$
\begin{aligned}
& \mathrm{Y} \quad=\text { Pendapatan petani kopi } \\
& \beta_{0} \quad=\text { Kostanta } \\
& \beta_{1} \beta_{2} \beta_{3} \quad=\text { Koefisien Regresi } \\
& \mathrm{X}_{1} \quad=\text { Luas lahan } \\
& \mathrm{X}_{2} \quad=\text { Tenaga Kerja } \\
& \mathrm{X}_{3} \quad=\text { Biaya Produksi } \\
& \text { ei }=\text { Error Term (variabel }
\end{aligned}
$$

pengganggu).

\section{HASIL PENELITIAN PEMBAHASAN}

\section{Uji Asumsi Klasik}

\section{Hasil Uji Normalitas}

Uji normalitas bertujuan untuk menguji apakah dalam model regresi, variabel pengguna atau residual memiliki distribusi normal. Untuk melihat normalitas residual penulis melihat dengan Jarque-Bera. Menurut (Rahmanta, 2009) normalitas dapat dideteksi dengan membandingkan nilai jarque-bera dengan $\kappa^{2}$ tabel yaitu:

a. Jika nila JB $<\Lambda^{2}$, maka residualnya berdistribusi tidak normal.

b. Jika nilai JB $>\Lambda^{2}$, maka residualnya berdistribusi normal. Bila nila JB tidak signifikan (lebih kecil dari 2), maka data berdistribusi normal.

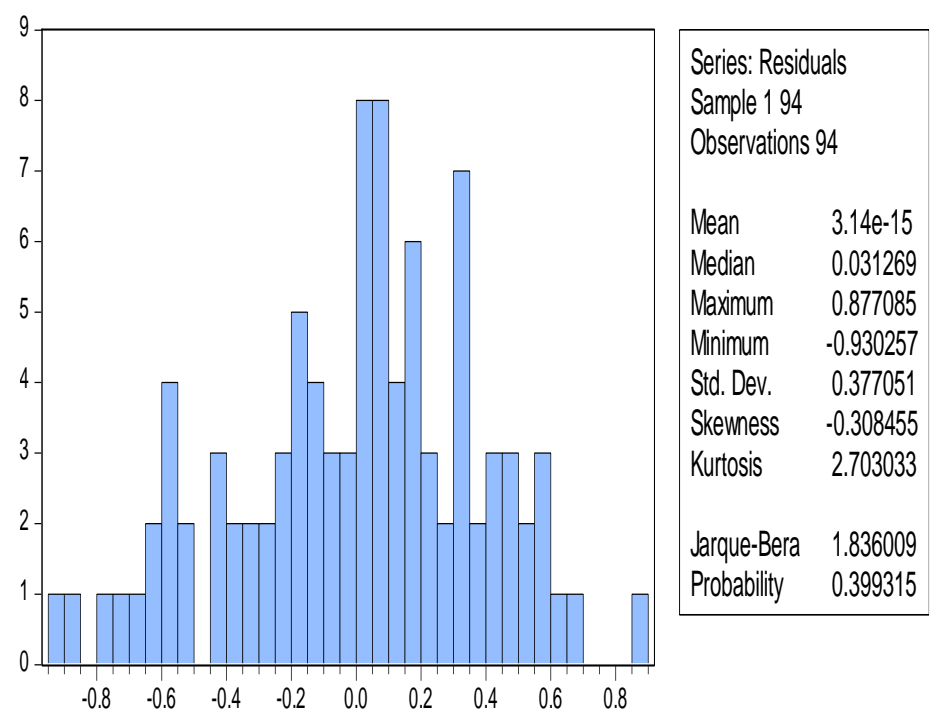

Sumber : Hasil Penelitian (data diolah), 2018

Untuk mengetahui normal atau tidaknya model regresi variabel penganggu atau residual dengan cara membandingkan nilai J-B hitung dengan nilai $K^{2}$ (Chi-Square) tabel dari Gambar 2 diproleh nilai J-B sebesar 1.836 nila $K^{2}$ tabel dengan $\mathrm{df}=94-4=90$ dengan df 3 sebesar 7,815, jika dibandingkan dengan nilai J-B pada gambar diatas sebesar 1,836, maka dapat disimpulkan bahwa data terdistribusi normal karena nilai J-B < nilai $K^{2}$ tabel atau $1,836<7,815$. Hal ini juga bisa dilihat dari probability Jarque-Berasebesar 0,399 $>0,05$, sehingga rsidual sudah berdistribusi dengan normal.

Heteroskedasticity Test: White

$\begin{array}{lrll}\text { F-statistic } & 0.825569 & \text { Prob. F(9,84) } & 0.5944 \\ \text { Obs }{ }^{\star} \text { R-squared } & 7.638964 & \text { Prob. Chi-Square(9) } & 0.5709 \\ \text { Scaled explained } & 5.962889 & \text { Prob. Chi-Square(9) } & 0.7436 \\ \text { SS } & 5\end{array}$

\section{Hasil Uji Heteroskedastisitas}

Uji Heteroskedastisitas bertujun untuk menguji ada atau tidaknya heteroskedastisitas dapat digunakan uji White. Jika nilai probabilitas signifikansinya di atas 0,05 maka dapat disimpulkan tidak terjadi heteroskedastisitas. Namun sebaliknya, jika nilai probabilitas signifikansinya di bawah 0,05 maka dapat dikatakan telah terjadi heteroskedastisitas. 


\section{Tabel 2}

\section{Uji Heteroskedastisitas}

Heteroskedasticity Test: White

\begin{tabular}{lrll}
\hline \hline F-statistic & 0.825569 & Prob. F(9,84) & 0.5944 \\
Obs $^{*}$ R-squared & 7.638964 & Prob. Chi-Square(9) & 0.5709 \\
Scaled explained SS 5.962889 & Prob. Chi-Square(9) & 0.7436 \\
\hline
\end{tabular}

Sumber : Hasil Penelitian (data diolah), 2018

Dari Tabel 1.3 diatas dapat dilihat bahwa nilai $O b s^{*} R$-Square untuk hasil adalah sebesar 7,638964 dan nilai tabel $\kappa^{2}$ dengan derajat kepercayaan 5\% adalah sebesar 16,919.Karena nilai $O b s^{*} R$-Square $7,6389<16,919$, dapat disimpulkan model ni terbebas dari gejala heteroskedastisitas. Hasil ini dapat dilihat dari nilai prob. Chi-square $>0,05$ atau 0,5709 $>0,05$, maka dari itu dapat dikatakan bahwa data dalam penelitian ini sudah baik dikarenakan memiliki kesamaan residual atau pengamatan dengan pengamatan yang lainnya dan dapat dilanjutkan untuk dianalisis melalui regresi linier berganda.

\section{Hasil Uji Multikolinieritas}

Uji multikolinieritas bertujuan untuk mendeteksi ada tidaknya multikolineritas yaitu dapat dilakukan dengan melihat (1) nilai tolelansi dan lawannya (2) variansi inflation (VIF). Kedua ukuran ini menunjukkan bahwa setiap variabel bebas manakah yang dijelaskan oleh variabel bebas lainnya. Nilai cutt of yang dipakai adalah nilai toleransi $>0,10$ atau sama dengan nilai VIF $<10$ atau menurut (Gujarati, 2012) multikolinieritas terjadi bila korelasi antar variabel bebas melebihi 0,80

Tabel 3

Hasil Uji Multikolinieritas

\begin{tabular}{|c|c|c|}
\hline $\begin{array}{c}\text { Variabel } \\
\text { Independen }\end{array}$ & $\mathrm{X} 1$ & $\mathrm{X} 2$ \\
\hline $\mathrm{X} 1$ & 1.000000 & -0.028013 \\
\hline $\mathrm{X} 2$ & -0.028013 & 1.00000 \\
\hline LOGX3 & 0.249518 & 0.11175 \\
\hline
\end{tabular}

Sumber : Hasil Penelitan (data diolah), 2018

Berdasarkan tabel 1.4 di atas dapat dilihat bahwa pada matriks korelasi antar variabel bebas dalam model regresi. Hasil olah data diketahui bahwa variabel bebas menunjukkan nilai sebesar 0,028013 dan 0,249518 yang berarti berada di bawah 0,80 , sehingga dapat disimpulkan bahwa dalam model ini tidak terdapat gangguan multikolinieritas.

\section{Estimasi Model Penelitian}

Hasil Estimasi Analisis Regresi Linier Berganda
Dengan menggunakan data primer yang diperoleh melalui kuesioner yang diisi oleh 94 responden petani kopi yang ada di Desa Wakil Jalil Kecamatan Bintang, maka peneliti melakukan analisis regresi linier berganda antar variabel bebas dengan variabel terikat dalam penelitian ini. Di mana yang menjadi variabel dependennya adalah pendapatan (Y), sementara yang menjadi variabel independennya adalah luas lahan $\left(\mathrm{X}_{1}\right)$, tenaga kerja $\left(\mathrm{X}_{2}\right)$, dan biaya produksi $\left(\mathrm{X}_{3}\right)$. Untuk mengetahui hasil penelitian ini dapat dilihat output regresi linier berganda (Multiple Regression Linier) dengan memakai Eviews 9.

Tabel 4

Hasil Pengolahan Data

Variable CoefficientStd. Error t-Statistic Prob.

C $\quad 10.27269 \quad 1.063894 \quad 9.655753 \quad 0.0000$

$\begin{array}{lllll}\text { LUAS_LAHAN } \quad 0.111881 & 0.040651 & 2.752197 & 0.0072\end{array}$

$\begin{array}{lllll}\text { TENAGA_KERJA } & 0.069499 & 0.033740 & 2.059865 & 0.0423\end{array}$

LOG(BIAȲA_PROD

$\begin{array}{lllll}\text { UKSI) } & 0.289461 & 0.080175 & 3.610363 & 0.0005\end{array}$

R-squared $\quad 0.264332$

Adjusted R-squared 0.239809

F-statistic $\quad 10.77925$

Prob(F-statistic) $\quad 0.000004$

Sumber : Hasil Penelitian (data diolah), 2018

Berdasarkan data Tabel 1.5 di atas, apabila dimasukkan dalam model penelitian, maka persamaan Irexis linier berganda (Multiple Regression Linear) adalah sebagai berikut : $0.249518=10.27269+0.111881 \mathrm{X}_{1}+$ $0.069499 \mathrm{X}_{2}+0.289461 \mathrm{LnX}_{3}$ Kostanta ( 30$)$ adalah sebesar 10.27269 yang berarti bahwla 099909 a variabel luas lahan, tenaga kerja dan biaya produksi dianggap konstan, maka pendapatan adalah sebesar 10.27269.

Parameter $\left(\beta_{1}\right)$ koefisien regresi dari luas lahan $\left(\mathrm{X}_{1}\right)$ sebesar 0.111881, apabila variabel luas lahan ditingkatkan $1 \mathrm{Ha}$, maka pendapatan akan meningkat sebesar Rp.0.111881, dengan asumsi variabel tenaga kerja dan biaya produksi konstan.

Parameter $\left(\beta_{2}\right)$ koefisien regresi dari tenaga kerja $\left(\mathrm{X}_{2}\right)$ sebesar 0.069499 , apabila variabel tenaga kerja ditingkatkan 1 jiwa, maka pendapatan akan meningkat sebesar Rp.0.069499, dengan asumsi luas lahan dan biaya produksi konstan. 
Parameter $\left(\beta_{2}\right)$ koefisien regresi dari biaya produksi $\left(\mathrm{X}_{3}\right)$ sebesar 0.289461 , apabila variabel biaya produksi ditingkatkan 1 rupiah, maka pendapatan akan meningkat sebesar Rp.0.289461, dengan asumsi variabel luas lahan dan tenaga kerja konstan.

Uji t digunakan untuk mengertahui variabel bebas mana yang dominan berpengaruh terhadap variabel terikat Adapun kriteria pengujiannya adalah sebagai berikut:

a. Jika $t_{\text {hitung }}>t_{\text {tabel }} \mathrm{H}_{0}$ ditolak dan menerima $\mathrm{H}_{\mathrm{a}}$ yang artinya variabel bebas $(\mathrm{X})$ secara parsial mempengaruhi variabel terikat (Y).

b. Jika $t_{\text {hitung }}<t_{\text {tabel }}$ maka $\mathrm{H}_{0}$ diterima dan menolak $\mathrm{H}_{\mathrm{a}}$ yang artinya artinya varaibel bebas (X) secara parsial tidak mempengaruhi variabel terikat (Y).

Pengujian secara parsial atau uji t, dengan tingkat signifikan (Level of Significant) atau $\alpha=5 \% \quad(\mathrm{df})=\mathrm{n}-\mathrm{k} \quad(94-4)=90$, sehingga nilai $\mathrm{t}_{\text {tabel }}$ diperoleh sebesar 1,986 .

Pembuktian untuk $\mathrm{H}_{1}$, dari hasil pengujian sebagaimana yang ditunjukkan pada Tabel 4.13, dapat dilihat bahwa variabel luas lahan memiliki nilai $t_{\text {hitung }}>t_{\text {tabel }}$ yaitu $2,752>1,986$, berarti secara parsial variabel luas lahan $\left(\mathrm{X}_{1}\right)$ berpengaruh positif terhadap pendapatan petani kopi di Desa Wakil Jalil Kecamatan Bintang Kabupaten Aceh Tengah.

Pembuktian untuk $\mathrm{H}_{2}$, variabel tenaga kerja $\left(\mathrm{X}_{2}\right)$ memiliki $t_{\text {hitung }}>\mathrm{t}_{\text {tabel }}$ yaitu $2,099>1,986$, berarti secara parsial tenaga kerja berpengaruh positif terhadap pendapatan petani kopi.

Pembuktian untuk $\mathrm{H}_{3}$, variabel biaya produksi memiliki $t_{\text {hitung }}>t_{\text {tabel }}$ yaitu $3,610>1,986$, berarti secara parsial biaya produksi berpengaruh positif terhadap pendapatan petani kopi.

\section{Uji Serentak (Uji F)}

Uji $F$ dilakukan untuk mengetahui ada tidaknya pengaruh nyata antar semua variabel bebas dan variabel terikat. Adapun kriteria pengujian yang digunakan sebagai berikut:

a. Jika $\mathrm{F}_{\text {hitung }}>\mathrm{F}_{\text {tabel }}$ maka $\mathrm{H}_{0}$ ditolak dan menerima $\mathrm{H}_{\mathrm{a}}$ yang artinya variabel bebas (X) secara serentak berpengaruh signifikan variabel terikat $(\mathrm{Y})$.

b. Jika $F_{\text {hitung }}<\mathrm{F}_{\text {tabel }}$ maka $\mathrm{H}_{0}$ diterima dan menolak $\mathrm{H}_{\mathrm{a}}$ yang artinya variabel bebas (X) secara serentak tidak berpengaruh signifikan variabel terikat (Y).
Berdasarkan hasil pengujian yang dilakukan maka dapat dilihat bahwa nila $F_{\text {hitung }}$ adalah 10,779 dengan taraf kepercayaan $95 \%$. sedangkan $\mathrm{F}_{\text {tabel }}$ df1 $(\mathrm{k}-1=4-1)$ df2 $(\mathrm{n}-\mathrm{k})=90-4)=(3)(90)$ adalah 2,71 pada $\alpha=5 \%$. Hal ini berarti $F_{\text {hitung }}>F_{\text {tabel }}$ yaitu $10,779>2,71$, dapat disimpulkan bahwa secara serempak atau secara bersama-sama variabel luas lahan, tenaga kerja dan biaya produksi berpengaruh positif terhadap pendapatan petani kopi di Desa Wakil Jalil Kecamatan Bintang Kabupaten Aceh Tengah.

\section{Hasil Koefisien Korelasi (R)}

Alat analisis koefisien korelasi yang digunakan yaitu metode pearson atau product moment. Nilai korelasi (r) berkisar antara 1 sampai -1 , nilai semakin mendekati 1 atau -1 berarti hubungan antara dua variabel semakin kuat, sebaliknya nilai mendekati 0 berarti hubungan antara dua variabel semakin lemah.

Untuk mengetahui tingkat korelasi ataupun hubungan antara variabel independen terhadap variabel dependen dapat dilihat dari nilai $R$ Squared. Nilai $R$-Squared diketahui sebesar $\sqrt{ } \mathrm{R}^{2}$ atau $\sqrt{ } 0,2398=0,4897$. Hal ini menunjukkan bahwa hubungan variabel luas lahan, tenaga kerja dan biaya produksi terhadap pendapatan berhubungan sangat lemah secara positif karena nilai korelasi sangat jauh dari angka 1.

\section{Hasil Koefisien Determinasi $\left(\mathbf{R}^{2}\right)$}

Nilai yang mendekati satu berarti variabelvariabel bebas memberikan hampir semua informasi yang dibutuhkan untuk memprediksi variabel terikat. Menurut (Gujarati, 2012) jika dalam uji empiris didapat nilai adjusted $\mathrm{R}^{2}$ negatif, maka niai adjusted $\mathrm{R}^{2}$ dianggap bernilai nol. Secara matematis jika nilai $\mathrm{R}^{2}=1$, maka adjusted $\mathrm{R}^{2}=\mathrm{R}^{2}=1$ sedangkan jika nilai $\mathrm{R}^{2}=0$, maka adjusted $R^{2}=(1-k) /(n-k)$, jika $k>1$, maka adjusted $\mathrm{R}^{2}$ akan bernilai negatif.

Koefisien determinasi $\left(\mathrm{R}^{2}\right)$ merupakan kondisi dimana variabel independen menjelaskan pengaruhnya terhadap variabel dependen. Dari hasil pengujian pada Tabel 4.13 dapat dilihat nilai Adjusted $R$-Squared memiliki nilai sebesar 0,2398 atau $23,98 \%$ dengan kata lain pengaruh variabel luas lahan, tenaga kerja dan biaya produksi adalah sebesar $23,98 \%$, sedangkan yang dipengaruhi oleh variabel lain di luar model ini adalah sebesar 0,7602 atau $76,02 . \%$. 


\section{Hasil Pembahasan}

\section{Hubungan Luas Lahan Terhadap Pendapatan}

Berdasarkan hasil pengujian bahwa luas lahan berpengaruh positif dan signfikan terhadap pendapatan petani kopi di Desa Wakil Jalil Kecamatan Bintang Kabupaten Aceh Tengah, dikarenakan jika luas lahan sempit maka hasil yang diperoleh juga sedikit dan mengakibatan pendapatan juga sedikit. Namun jika luas lahan yang dimiliki petani besar maka akan menghasilkan keuntungan dan apabila djual akan menguntungkan para petani kopi tetsebut. Luas lahan memepengaruhi skala usahatani yang pada akhirnya mempengaruhi tingkat efesiensi suatu usaha tani yang dijalankan. Hasil Penelitian ini sama dengan penelitian (Supriyadi, 2014) dengan judul skripsi Analisis Pendapatan Usaha Tani Kopi (Coffee Sp) Rakyat Di Kecamatan Limbangan Kabupaten Kendal, dimana luas lahan, biaya produksi, hasil produksi, dan pendidikan berpengaruh terhadap pendapatan petani di Kecamatan Limbangan Kabupaten Kendal. Dilihat dari kondisi yang terjadi di Desa Wakil Jalil luas lahan merupakan faktor penentu dalam mendapatkan penghasilan para petani kopi tersebut, jika dilihat dari data observasi yang dilakukan bahwa luas lahan yang ada di Desa Wakil Jalil tidak terlalu luas.

\section{Hubungan Tenaga Kerja Terhadap Pendapatan}

Berdasarkan hasil pengujian bahwa tenaga kerja berpengaruh secara positif terhadap pendapatan petani di Desa Wakil Jalil, dikarenakan tenaga kerja yang digunakan yaitu tenaga kerja yang dari luar keluarganya sendiri, semakin banyak tenaga kerja semakin banyak hasil produksi yang dihasilkan akan tetapi berpengaruh terhadap pendapatan petani karena harus membayar setiap tenaga kerja. Pada dasarnya tanaman kopi merupakan tanaman yang sangat mudah untuk dirawat oleh para petani, tidak perlu menggunakan tenaga kerja dalam hal produksi cukup tenaga kerja dari keluarga sendiri yang digunakan dalam produksi. Jika menggunakan tenaga kerja dari luar keluarga sendiri bararti harus mengeluarkan uang untuk membayar upah tenaga kerja tersebut ini akan mengurangi tingkat pendapatan para petani kopi.

\section{Hubungan Biaya Produksi Terhadap Pendapatan}

Berdasarkan hasil pengujian bahwa biaya produksi berpengaruh secara positif tehadap pendapatan petani kopi di Desa Wakil Jalil, dikarenakan faktor biaya adalah salah satu penunjang untuk keberhasilan suatu pendapatan. Semakin besar biaya produksi dan semakin kecil biaya produksi maka akan mempengaruhi pendapatan yang akan diterima. Biaya produksi tidak hanya digunakan untuk membeli obatobatan, pupuk, bibit akan tetapi biaya produksi bisa digunakan untuk membayar upah tenaga kerja yang telah bekerja.biaya produksi sangat mempengaruhi pendapatan para petani tersebut, untuk mengahasilkan tanaman yang bagus dan terhindar dari hama penyakit para petani harus mengeluarkan biaya untuk perawatan tanaman tersebut, dimana semakin besar biaya yang dikeluarkan maka semakin besar pula hasil yang diterima.

\section{PENUTUP}

\section{Kesimpulan}

Berdasarkan hasil penelitian diatas, maka dapat diambil kesimpulan sebagai sberikut:

1. Secara parsial variabel luas lahan berpengaruh positif dan signifikan terhadap pendapatan petani kopi di Desa Wakil Jalil Kecamatan Bintang Kabupaten Aceh Tengah.

2. Secara parsial variabel tenaga kerja berpengaruh positi terhadap pendapatan petani kopi di Desa Wakil Jalil Kecamatan Bintang Kabupaten Aceh Tengah.

3. Secara parsial variabel biaya produksi berpengaruh positif terhadap pendapatan pendapatan petani kopi di Desa Wakil Jalil Kecamatan Bintang.

4. Variabel luas lahan, tenaga kerja dan biaya produksi secara serentak atau secara bersamasama berpengaruh positif terhadap pendapatan petani kopi di Desa Wakil Jalil Kecamatan Bintang Kabupaten Aceh Tengah.

\section{Saran}

Berdasarkan hasil penelitian diatas, maka saran yang dapat diberikan adalah:

1. Untuk meningkatkan pendapatan petani kopi, petani harus pandai dalam mengeluarkan biaya produksi supaya pendapatan lebih menguntungkan lagi.

2. Bagi peneliti selanjutnya, disarankan untuk memperbanyak sensus yang digunakan agar hasilya lebih represntatif terhadap populasi yang akan dipilih. Variabel yang digunakan dalam penelitian selanjutnya diharapkan lebih 
lengkap dan bervariasi lagi dengan menambahkan variabel independen yang lain, baik itu ukuran-ukuran yang mempengaruhi pendapatan petani

\section{KEPUSTAKAAN}

Amirullah Dan Harjanto. (2005). Pengantar Bisnis (Edisi 1). Yogyakarta: Graha Ilmu.

Gujarati N.D. (2012). Basic Ekonometrika. Jakarta: Salemba Empat.

Kantor Camat Kecamatan Bintang. (2018). Kabupaten Aceh Tengah Dalam Angka 2017.

Maihani, S. (2017). Mewujudkan Perkopian Nasional Dan Berwawasan Lingkungan Dalam Pengembangan Industri Kopi Bubuk Skala Kecil Untuk Meningkatkan Nilai Tambah Usaha Tani kopi Rakyat Di Aceh Tengah. Jurnal Ilmiah Sains, Teknologi, Ekonomi, Sosial Dan Budaya, Volume 1(No 1), Halaman 1-7.

Mubyarto. (2004). Ekonomi Rakyat Program IDT dan Demokrasi Ekonomi Indonesua. Jakarta: Penerbit Aditya Media.

Mubyarto. (2007). Pengantar Ekonomi Pertanian. Jakarta: LP3ES.

Rahmanta. (2009). Modul Aplikasi Eviews Dalam Ekonometrika. Medan: Modul Fakultas Pertanian USU.

Setiyowati, D. (2016). Faktor-Faktor Yang Mempengaruhi Pendapatan Petani Bawang Merah Di Desa Tirtohargo, Kecamatan Kretek Kabupaten Bantul, Provinsi Daerah Istimewa Yogyakarta. Jurnal Ekonomi , Fakultas Ekonomi Dan Bisnis, Volume 1(No 1), Halaman 1-19.

Simanjuntak, J. . (2011). Pengantar Ekonomi Sumber adaya Manusia. Jakarta: LP-FE, UI.

Soekartawi, A., Suharjo, J. ., \& J.B.H Dillon. (2011). Ilmu Usaha Tani Penelitian Untuk Pengembangan Petani kecil. Jakarta: Universitas Indonesia Pers.

Soekartawi A, Suharjo, J. ., \& J, B, H. D. (2006). Analisis Usahatani. Jakarta: Universitas Indonesia Pers.

Sugiyono. (2015). Statistik Untuk Penelitian. Bandung: Alfabeta.
Supranto. (2003). Perencanaan Manajemen. Jakarta: Elemekdia Compotindo.

Supriyadi, A., Wahyuningsih, S., \& Awahmi, S. . (2014). Faktor-Faktor Yang Mempengaruhi Pendapatan Usahatani kopi (Coffea sp) Rakyat Di Kecamatan Limbangan Kabupaten Kendal. Jurnal Agribisnis Fakultas Pertanian, Universitas Wahid Hasyim, Volume 8(No 1), Halaman 1-15. 